\title{
PEMAHAMAN MANAJEMEN TENTANG PERATURAN PERPAJAKAN DALAM HUBUNGANNYA DENGAN KEPATUHAN WAJIB PAJAK BADAN \\ (Studi Kasus pada KPP Tanjung Karang)
}

\author{
Syamsu Rizal, Universitas Bandar Lampung \\ Nia Fitri Sari, Universitas Bandar Lampung \\ Haninun, Universitas Bandar Lampung
}

\begin{abstract}
As for the purpose and benefits of this research is to know the extent to which the understanding of management are registered on the KPP Pratama Tanjung Karang in understanding taxation regulations in Cape Coral and to analyze the relationship between management's understanding of the KPP Pratama Tanjung is listed on the Reef about compliance with tax regulations tax payers of existing agencies in Cape Coral as well as add insight/understanding of taxation regulations against the Taxpayer's compliance with the Agency. Based on the above issues, then set the following hypothesis:\% u201CTerdapat relationship between management's understanding of the law No. 36 year 2008 against Taxpayer compliance Agency on law No. 28 of 2007
\end{abstract}

Keywords : Management understanding, taxation regulations, Agency's taxpayer compliance

\section{LATAR BELAKANG}

Saat ini, bisnis dan pajak tidak bisa dilepaskan satu sama lain. Di mana ada potensi keuntungan ekonomis, di situ biasanya akan ada kegiatan bisnis. Di mana pun ada bisnis di situ ada pajak yang mewakili kepentingan negara. Semua kegiatan berbisnis tidak akan luput dari kewajiban pajak. Untuk penyerahan barang dan atau jasa yang dilakukan akan ada kewajiban memungut, menyetor dan melaporkan Pajak Pertambahan Nilai (PPN).

Untuk itu terdapat berbagai kewajiban administratif yang harus dijalankan seperti membuat Faktur Pajak, mengisi Surat Setoran Pajak (SSP) kemudian menyetorkannya ke kas negara melalui bank persepsi atau kantor pos dan mengisi Surat Pemberitahuan (SPT) dan kemudian melaporkannya ke Kantor Pelayanan Pajak (KPP) di mana pengusaha tersebut terdaftar. Bila dalam menjalankan bisnisnya diperoleh keuntungan, maka yang bersangkutan harus membayar Pajak Penghasilan (PPh).

Pada umumnya Wajib Pajak mempunyai kecenderungan untuk menghindar dari kewajibannya dalam membayar pajak. Kecenderungan melakukan penghindaran yang dilakukakan oleh Wajib Pajak dalam pemenuhan kewajiban perpajakan lebih banyak terjadi karena Indonesia menggunakan sistem pemunggutan pajak self assesment. Sistem pemunggutan ini memberikan peran aktif kepada Wajib Pajak untuk melakukan sendiri perhitungan pajak terutang, menyetorkan sendiri dan melaporkan surat pemberitahuan sendiri (SPT).

Dalam sistem ini menekankan untuk kerelaan Wajib Pajak dan kesadaran Wajib Pajak dalam mematuhi peraturan perpajakan. Agar sistem self assesment berjalan secara 
efektif, keterbukaan, dan pelaksanaan penegakkan hukum ini dapat dilakukan dengan adanya pemeriksanan, penyelidikan pajak dan penagihan pajak. Pemeriksaan merupakan instrumen yang baik untuk meningkatkan kepatuhan Wajib Pajak, baik formal maupun materil dari peraturan perpajakan, yang tujuan utamanya untuk menguji dan meningkatkan kepatuhan Wajib Pajak.

\section{TELAAH LITERATUR DAN PENGEMBANGAN HIPOTENSI}

\subsection{Pengertian manajemen}

Manajemen adalah suatu proses atau kerangka kerja, yang melibatkan bimbingan atau pengarahan suatu kelompok orang-orang kearah tujuan-tujuan organisasional atau maksudmaksud yang nyata. Manajemen juga adalah suatu ilmu pengetahuan maupun seni. Seni adalah suatu pengetahuan bagaimana mencapai hasil yang diinginkan atau dalam kata lain seni adalah kecakapan yang diperoleh dari pengalaman, pengamatan dan pelajaran serta kemampuan untuk menggunakan pengetahuan manajemen.

\subsubsection{Tingkatan Manajemen (Management Functions)}

Tingkatan manajemen dilihat dari tingakatan organisasi, manajemen dibagi dalam 3 tingkatan yaitu:

1. Manajemen Puncak (Top Management)

Manajer bertaggungjawab atas pengaruh yang ditimbulkan dari keputusankeputusan manajemen keseluruhan dari organisasi.

2. Manajemen Menengah (Middle Management)

Manajemen menengah harus memeiliki keahlian interpersonal/manusiawi, artinya keahlian untuk berkomunikasi, bekerjasama dan memotivasi orang lain. Manajer bertanggungjawab melaksanakan rencana dan memastikan tercapainya suatu tujuan.

3. Manajemen Bawah (Lower Management)

Manager bertanggung jawab menyelesaikan rencana-rencana yang telah ditetapkan oleh para manajer yang lebih tinggi. Pada tingkatan ini juga memiliki keahlian yaitu keahlian teknis, artinya keahlian yahng mencakup prosedur, teknik, pengetahuan dan keahlian dalam bidang khusus. Misal: supervisor, accounting.

\subsubsection{Pajak}

Pajak adalah prestasi yang dipaksakan sepihak oleh dan terutang kepada pengusaha (menurut norma-norma yang ditetapkannya secara umum), tanpa adanya kontraprestasi, dan semata-mata digunakan untuk menutupi pengeluaran-pengeluaran umum. Karena pajak merupakan prestasi kepada pemerintah yang terutang melalui norma-norma umum yang dapat dipaksakannya, tanpa adanya kontraprestasi yang dapat ditunjukan dalam hal individual, dimaksudkan untuk membiayai pengeluaran pemerintah. Pajak juga dikatakan sebagai suatu pengalihan sumber dari sektor swasta ke sektor pemerintah, bukan akibat pelanggaran hukum, namun wajib dilaksanakan, berdasarkan ketentuan yang ditetapkan lebih dahulu, tanpa mendapat imbalan yang langsung dan proposional, agar pemerintah dapat melaksanakan tugas-tugasnya untuk menjalankan pemerintahan. 


\subsubsection{Wajib Pajak}

Self Assessment System adalah suatu sistem yang memberikan kepercayaan dan tanggung jawab kepada Wajib Pajak untuk menghitung, memperhitungkan dan membayar sendiri jumlah pajak yang terutang sesuai dengan ketentuan perpajakan yang berlaku. Selain itu Wajib Pajak diwajibkan pula melaporkan secara teratur jumlah pajak yang terutang dan telah dibayar sebagaimana ditentukan dalam peraturan perpajakan. Pada sistem ini, masyarakat Wajib Pajak diberikan kepercayaan dan tanggung jawab yang lebih besar untuk melaksanakan kewajibannya, yaitu menghitung, memperhitungkan, membayar serta melaporkan. Untuk menyukseskan self assessment system dibutuhkan beberapa persyaratan dari Wajib Pajak yaitu :

- Kesadaran Wajib Pajak

- Kejujuran Wajib Pajak

- Kemauan membayar pajak dari Wajib Pajak

- Kedisiplinan Wajib Pajak

a) Menghitung yaitu menghitung besarnya pajak yang terutang yang dilakukan pada setiap akhir bulan (untuk PPN dan PPnBM) dan akhir tahun (untuk PPh), dengan cara :

Tarif pajak X DPP = Pajak Terutang

b) Memperhitungkan yaitu mengurangkan pajak yang terutang dengan jumlah pajak yang sudah dilunasi dalam tahun berjalan yang dikenal dengan nama Kredit Pajak, yaitu:

Selisih antara Pajak yang terutang dengan kredit pajak dapat berupa:

- Kurang Bayar PT - KP

Kurang bayar terjadi karena jumlah pajak terutang lebih besar dari kredit pajak, yang harus dilunasi paling lambat tanggal 25 Maret setelah tahun pajak atau bagian pajak berakhir, sebelum SPT tahunan disampaikan paling lambat tanggal 31 Maret.

- Lebih Bayar PT<KP $\quad \mathrm{PT}>\mathrm{KP}$

Lebih bayar terjadi karena jumlah pajak yang terutang lebih kecil dari kredit pajak, yang dapat dimintakan restitusi atau dilakukan kompensasi.

- Nihil Bayar PT=KP

Nihil bayar terjadi apabila jumlah pajak terutang sama dengan kredit pajak.

c) Menyetorkan atau membayar yaitu Wajib Pajak membayarkan sendiri besarnya pajak terhutang sesuai dengan besarnya pajak terutang.

d) Melaporkan yaitu Wajib Pajak melaporkan atau menyampaikan laporan sisa pajak terutang yang akan dilunasi pada akhir tahun.

\section{Kewajiban Wajib Pajak:}

1) Mendaftarkan diri dan meminta Nomor Pokok Wajib Pajak (NPWP) apabila belum mempunyai NPWP.

2) Mengambil sendiri blangko Surat Pemberitahuan (SPT) dan blangko perpajakan lainnya di tempat-tempat yang ditentukan oleh DJP. 
3) Mengisi dengan lengkap, jelas dan benar dan menandatangani sendiri SPT dan kemudian mengembalikan SPT itu kepada kantor inspeksi pajak dilengkapi dengan lampiran-lampiran.

4) Melakukan pelunasan dan melakukan pembayaran pajak yang ditentukan oleh UndangUndang.

5) Menghitung sendiri, menetapkan besarnya jumlah dan membayar pajak dalam tahun yang sedang berjalan, sesuai dengan pajak dari tahun terakhir atau sesuai dengan SKP yang dikeluarkan oleh DJP.

6) Menghitung dan menetapkan sendiri pajak yang terutang menurut cara yang ditentukan.

7) Menyelenggarakan pembukuan atau pencatatan-pencatatan.

8) Dalam hal terjadi pemeriksaan pajak, Wajib Pajak wajib:

- Memperlihatkan dan atau meminjamkan buku atau catatan, dokumen yang menjadi dasarnya dan dokumen lain yang berhubungan dengan penghasilan yang diperoleh, kegiatan usaha, pekerjaan bebas Wajib Pajak atau objek yang terutang pajak.

- Memberikan kesempatan untuk memasuki tempat atau ruang yang dipandang perlu dan memberi bantuan guna kelancaran pemeriksaan.

- Memberikan keterangan yang diperlukan.

\section{Hak-hak Wajib Pajak:}

1). Menerima tanda bukti pemasukan SPT.

2). Mengajukan permohonan dan penundaan penyampaian SPT.

3). Melakukan pembetulan sendiri SPT yang telah dimasukkan ke KPP.

4). Mengajukan permohonan penundaan dan pengangsuran pembayaran pajak sesuai dengan kemampuannya.

5). Mengajukan permohonan perhitungan atau pengembalian kelebihan pembayaran pajak serta berhak memperoleh kepastian terbitnya surat keputusan kelebihan pembayaran pajak, surat keputusan pengembalian kelebihan pembayaran pajak.

6). Mendapatkan kepastian batas ketetapan pajak yang terutang dan penerbitan Surat Pemberitaan.

7). Mengajukan permohonan pembetulan salah tulis atau salah hitung atau kekeliruan yang terdapat dalam Surat Ketetapan Pajak (SKP) dalam penerapan peraturan perundangundangan perpajakan.

8). Mengajukan surat keberatan dan mohon kepastian terbitnya surat keputusan atas surat keberatannya.

9). Mengajukan permohonan banding atas surat keputusan keberatan yang diterbitkan oleh DJP.

\subsubsection{Kepatuhan Wajib Pajak}

Kepatuhan pajak dapat didefinisikan sebagai suatu keadaan Wajib Pajak memenuhi semua kewajiban perpajakan dan melaksanakan hak perpajakannya sesuai dengan ketentuan peraturan perundangan yang berlaku. Kepatuhan pajak ada dua jenis yaitu:

1) Kepatuhan Formal yaitu suatu keadaan dimana wajib pajak memenuhi kewajiban perpajakan secara formal sesuai dengan ketentuan perundang-undangan perpajakan yang berlaku.

2) Kepatuhan Materil yaitu suatu keadaan dimana wajib pajak secara subtantif atau hakikatnya memenuhi semua ketentuan material perpajakan yakni sesuai dengan isi dan jiwa Undang-Undang Perpajakan. 


\subsubsection{Surat Pemberitahuan (SPT)}

Surat Pemberitahuan (SPT) diterima adalah SPT yang dilaporkan setiap tahunnya dan diterima oleh KPP setempat. Secara fungsional SPT merupakan sarana komunikasi antara wajib pajak dan fiskus. Bagi wajib pajak merupakan sarana pertanggungjawaban kewajiban perpajakan selama satu periode fiskal, sedang bagi fiskus sebagai sarana pamantauan terhadap pemenuhan kewajiban perpajakan Wajib Pajak. Secara fisik SPT adalah formulir yang telah disiapkan fiskus untuk diisi Wajib Pajak guna melaporkan pemenuhan kewajiban perpajakannya. Menurut UU No.28 tahun 2007 pasal 1ayat 1, Surat Pemberitahuan adalah surat yang oleh Wajib Pajak digunakan untuk melaporkan penghitungan atau pembayaran pajak, objek pajak atau bukan objek pajak, atau harta dan kewajiban sesuai dengan ketentuan peraturan perundang-undangan perpajakan.

\section{Jenis dan Fungsi SPT}

Jenis SPT dibedakan menjadi dua yaitu:

1. Surat Pemberitahuan (SPT) Masa merupakan surat yang oleh wajib pajak digunakan untuk melaporkan perhitungan dan atau pembayaran pajak terutang dalam suatu masa pajak.

2. Surat Pemberitahuan (SPT) Tahunan merupakan surat yang oleh wajib pajak dipergunakan untuk melaporkan perhitungan dan pembayaran pajak terutang dalam suatu tahun pajak.

Adapun fungsi SPT bagi wajib pajak penghasilan yaitu:

1. Sarana melapor dan mempertanggungjawabkan penghitungan pajak sebenarnya terutang.

2. Melapor pembayaran atau pelunasan pajak yang telah dilaksanakan sendiri dan atau melalui pemotongan atau pemungutan pihak lain dalam satu tahun atau bagian tahun pajak.

3. Melaporkan pembayaran dari pemotong atau pemungut tentang pemotongan atau pemungutan pajak orang pribadi atau badan lain dari satu Masa Pajak sesuai dengan peraturan perundang-undangan perpajakan yang berlaku.

\section{Batas Waktu Penyampaian SPT}

Menurut Undang-undang Nomor 28 Tahun 2007 Pasal 3 ayat (3) tentang Ketentuan Umum dan Tata Cara Perpajakan, batas waktu penyampaian SPT adalah:

a. Batas waktu penyampaian SPT Masa paling lambat 20 (dua puluh) hari setelah akhir masa pajak.

b. Batas waktu penyampaian SPT Tahunan PPh WP badan paling lambat 4 (empat) bulan setelah akhir tahun pajak.

\subsubsection{Surat Ketetapan Pajak (SKP)}

Surat Ketetapan Pajak (SKP) merupakan surat ketetapan pajak yang meliputi:

1. Surat Ketetapan Pajak Kurang Bayar (SKPKB)

SKPKB adalah surat keputusan yang menentukan besarnya jumlah pajak yang terhutang, jumlah kredit pajak, jumlah kekurangan pembayaran pokok pajak, besarnya sanksi administrasi dan jumlah yang masih harus dibayar. (UU No.28 tahun 2007 pasal 1 ayat 16). 
2. Surat Ketetapan Pajak Kurang Bayar Tambahan (SKPKBT)

SKPKBT adalah surat keputusan yang menentukan tambahan atas jumlah pajak yang telah ditetapkan.

3. Surat Ketetapan Pajak Lebih Bayar (SKPLB)

SKPLB adalah surat keputusan yang menentukan jumlah kelebihan pembayaran pajak karena jumlah kredit pajak lebih besar dari pajak yang terhutang atau tidak seharusnya terhutang. Fungsi SKPLB adalah sebagai alat atau sarana untuk menentukan jumlah kelebihan pembayaran pajak karena jumlah kredit pajak lebih besar dari pajak yang terhutang atau tidak seharusnya terhutang.

4. Surat Ketetapan Pajak Nihil (SKPN)

SKPN adalah surat keputusan yang menentukan jumlah PPh terhutang sama besarnya dengan kredit pajak. (UU No.28 tahun 2007 pasal 1 ayat 18).

\subsubsection{Pemeriksaan Pajak}

\section{Pengertian Pemeriksaan Pajak}

Pemeriksaan adalah serangkaian kegiatan untuk mencari, mengumpulkan, dan mengolah data dan atau keterangan lainnya untuk menguji kepatuhan pemenuhan kewajiban perpajakan dan untuk tujuan kain dalam rangka melaksanakan peraturan perundangundangan perpajakan (pasal 1 ayat 25 UU No.28 tahun 2007). Jumlah pemeriksaan pajak ini dapat diukur dengan jumlah Surat Ketetapan Pajak yang diterbitkan oleh KPP.

\section{Tujuan Pemeriksaan Pajak}

Dalam pasal 29 ayat (1) dikatakan "Direktur Jenderal Pajak berwenang melakukan pemeriksaan untuk menguji kepatuhan pemenuhan kewajiban perpajakan dan untuk tujuan lain dalam rangka melaksanakan ketentuan perundang-undangan perpajakan. Tujuan pemeriksaan adalah untuk menguji kepatuhan pemenuhan kewajiban perpajakan, bukan sekedar untuk menerbitkan surat ketetapan pajak, apalagi demi kepentingan kas Negara. Jadi surat ketetapan pajak dapat timbul sebagai akibat dari pemeriksaan pajak bukan tujuan pemeriksaan.

\section{Laporan Pemeriksaan Pajak dan Penyelesaiannya}

Laporan pemeriksaan pajak adalah laporan tentang hasil pemeriksaan yang disusun oleh Pemeriksa Pajak secara ringkas dan jelas serta sesuai dengan ruang lingkup dan tujuan pemeriksaan laporan pemeriksaan pajak digunakan sebagai dasar penerbitan Surat Ketetapan Pajak (SKP) atau untuk tujuan lain dalam rangka pelaksanaan peraturan perundang-undangan perpajakan. Jenis SKP yang dapat terbit dari setiap pemeriksaan sesuai dengan jenis pajak yang diperiksa oleh fiscus. Penghitungan besarnya pajak terhutang menurut Laporan Pemeriksaan Pajak diberitahukan kepada Wajib Pajak, kecuali pemeriksaan akan dilanjutkan dengan tindakan penyelidikan.

\section{METODE PENELITIAN}

\subsection{Objek Penelitian}

Objek yang digunakan dalam penelitian ini adalah perusahaan yang terdaftar di Kantor Pelayanan Pajak Pratama Tanjung Karang. 


\subsubsection{Populasi}

Populasi adalah suatu kesatuan individu atau subjek pada wilayah dan waktu dengan kualitas tertentu yang akan diamati/diteliti. Atau dengan kata lain populasi merupakan keseluruhan data yang dijadikan sebagai analisis/pembahasan dalam penelitian. Dalam penelitian ini yang menjadi populasinya adalah jumlah Wajib Pajak badan yang terdaftar di Kantor Pelayanan Pajak Pratama Tanjung Karang berjumlah 250 perusahaan besar.

\subsubsection{Sampel}

Sampel merupakan bagian dari populasi yang dijadikan subjek penelitian. Berdasarkan populasi yang ada, akan diambil sebesar sampel tertentu dengan menggunakan teknik sampel judgment sampling yaitu sampel dipilih berdasarkan penilaian peneliti bahwa dia adalah pihak yang paling baik untuk dijadikan sampel penelitiannya. Dalam penelitian ini yang merupakan orang yang terbaik untuk bisa memberikan informasi dan memperoleh data tentang bagaimana suatu manajemen perusahaan dalam menangani proses perpajakan dalam suatu perusahaan adalah manajer tingkat bawah (lower management) yang langsung memimpin staff dalam menghitung pajak. Jumlah sampel dalam penelitian ini yang menjadi sampel sebanyak $10 \%$ dari 250 perusahaan, maka menjadi 25 perusahaan.

\subsection{Pengumpulan Data}

\subsubsection{Jenis Data}

1. Data primer yaitu data yang diperoleh secara langsung dari objek penelitian dengan cara kuesioner dan dokumentasi.

2. Data sekunder yaitu data yang diperoleh dari studi kepustakaan dan dokumentasi dengan cara berhubungan dengan permasalahan dalam penelitian ini.

\subsubsection{Metode Pengumpulan Data}

a). Penelitian Kepustakaan

Penelitian ini untuk mendapatkan data yang bersifat teoritis, mengenai hal-hal yang berkaitan dengan pokok pembahasan, dan dilakukan dengan cara membaca bebagai literatur-literatur dan sumber pustaka lainnya, yang berkaitan dengan penelitian.

b). Kuesioner

Teknik ini dengan memberikan form pertanyaan yang sudah dengan pilihan jawaban tersedia kepada objek penelitian (SKPD) yang ditunjukkan kepada manajemen perpajakan.

a. Dokumentasi

Teknik pengumpulan data yang dilakukan dengan cara melakukan kategorisasi, pengelompokan atau klasifikasi data dari bahan-bahan tertulis yang berhubungan dengan masalah penelitian baik dari sumber-sumber dokumen maupun buku-buku, internet, dan lain-lain.

\subsection{Variabel dan Pengukuran}

Operasional variabel menjelaskan variabel-variabel sesuai dengan fungsi atau kedudukan sebagai variabel independent $(\mathrm{X})$ dan variabel dependent (Y).Dalam penelitian ini yang merupakan variabel independent $(\mathrm{X})$ adalah pemahaman manjemen tentang UU No.36 thn 2008 (PPh), sedangkan variabel dependent (Y) adalah kepatuhan Wajib Pajak badan pada UU No.28 thn 2007 (KUP). 


\subsection{Metode Analisis Data}

Secara terperinci metode analisis yang digunakan untuk mengetahui tingkat kepatuhan wajib pajak Badan yang diajukan dalam penelitian ini dapat dijelaskan sebagai berikut:

\subsubsection{Analisis Kualitatif}

Pada bagian ini akan dibahas mengenai hasil penelitian dengan memberikan penilaian terhadap jawaban responden mealui penyebaran kuisioner yang telah diisi responden terhadap indikator dari variabel yang diteliti. Skala yang digunakan adalah skala Likert dan skala Interval.

1. Skala interval mengetahui tanggapan responden terhadap variabel penelitian. Skala interval mempunyai kriteria penilaian $1-5$, dengan menggunakan rumus rumus sebagai berikut :

$$
\text { I = }
$$

2. Skala Likert untuk mengetahui tanggapan responden terhadap masing-masing butir instrumen indikator. Skala likert mempuyai kriteria penilaian $1-5$.

\subsubsection{Analisis Kuantitatif}

Secara kuantitatif penulis menganalisa data dari hasil jawaban kuisioner dengan pendekatan Analisis Korelasi Sederhana melalui Microsoft Office Excel 2007 untuk mengetahui apakah ada korelasi antara variabel $\mathrm{X}$ dan variabel $\mathrm{Y}$ linier atau tidak. Penulis menggunakan analisis statistik untuk mengukur tingkat korelasi antara variabel-variabel penelitian, yaitu :

1. Untuk mengetahui Hubungan Pemahaman manajemen tentang UU No.36 tahun 2008 (PPh) terhadap kepatuhan Wajib Pajak badan pada UU No.28 tahun 2007 (KUP) maka digunakan alat uji berupa rumus koofisien korelasi. (Winarno Surachmat, 1997 : 18) sebagai berikut :

Di mana :

$$
r=\frac{n \cdot \sum X \cdot Y-\sum X \cdot \sum Y}{\sqrt{n \cdot \sum X^{2}-\sum X^{2}} \sqrt{n \cdot \sum Y^{2}-\sum Y^{2}}}
$$

$\mathrm{R}=$ Korelasi

$\mathrm{X}=$ Jumlah skor-skor $\mathrm{X}$

$\mathrm{Y}=$ Jumlah skor-skor $\mathrm{Y}$

$\mathrm{X}^{2}=$ Jumlah skor-skor $\mathrm{X}$ yang dikuadratkan

$\mathrm{Y}^{2}=$ Jumlah skor-skor $\mathrm{Y}$ yang dikuadratkan

$\mathrm{XY}=$ Jumlah dari hasil perkalian antara skor $\mathrm{X}$ dan skor $\mathrm{Y}$

$\mathrm{n}=$ Banyaknya sampel

$\sum=$ Sigma/jumlah

Dengan ketentuan nilai $r$ sebagai berikut :

1. $r=0$ atau mendekati 0 , maka hubungan kedua variabel sangat lemah atau tidak ada hubungan sama sekali.

2. $r=1$ atau mendekati 1 , maka hubungan antara kedua variabel kuat sekali atau cukup kuat dan mempunyai hubungan searah.

3. $\mathrm{r}=-1$ atau mendekati -1, maka kedua variabel kuat sekali atau cukup kuat dan mempunyai hubungan terbalik (negatif). 
Sedangkan untuk data interprestasi tentang arah hubungan tingkat keeratan antara variabel bebas dan variabel terikat dengan kriteria sebagai berikut :

\begin{tabular}{|l|c|}
\hline \multicolumn{1}{|c|}{ Interpretasi } & Interval \\
\hline Korelasi Sangat Rendah & $0,01-0,20$ \\
\hline Korelasi Rendah & $0,21-0,40$ \\
\hline Korelasi Sedang & $0,41-0,60$ \\
\hline Korelasi Tinggi & $0,61-0,80$ \\
\hline Korelasi Sangat tinggi & $0,81-1,00$ \\
\hline
\end{tabular}

2. Menghitung koefesien korelasi determinasi ( $r$ square atau $r^{2}$ ) untuk mengetahui seberapa jauh tingkat derajat asosiasi variabel $\mathrm{X}$ terhadap variabel $\mathrm{Y}$, serta untuk mengetahui berapa besar persentase kekuatan pengaruh variabel $X$ dari sampel yang dipilih dapat dijelaskan oleh variabel Y, dengan analisis KP sebagai berikut:

$\mathrm{KP}=\mathrm{r}^{2} \times 100 \%$

Dimana:

KP : Kofisien Penentu

$\mathrm{r} \quad$ : Kofisien Korelasi

3. Melakukan uji statistik

Uji statistik dilakukan untuk menguji signifikan koefesien regresi yang diperoleh, Langkah-langkah untuk melakukan uji $\mathrm{t}$ adalah:

a. Hipotesis

Ho : pemahaman manajemen tentang UU No.36 tahun 2008 (X) tidak berpengaruh positif dan signifikan terhadap kepatuhan Wajib Pajak badan pada UU No.28 tahun 2007 (Y).

Ha : pemahaman manajemen tentang UU No.36 tahun 2008 (X) berpengaruh positif dan signifikan terhadap kepatuhan Wajib Pajak badan pada UU No.28 tahun 2007 (Y).

b. Uji statistik

Dasar pengambilan keputusan dengan membandingkan nilai $t_{\text {hitung }}$ dengan $t_{\text {tabel }}$

- Jika statistik $t_{\text {hitung }}>$ statistik $t_{\text {tabel}}$, maka Ho ditolak \& Ha diterima

- Jika statistik $t_{\text {hitung }}<$ statistik $\mathrm{t}_{\text {tabel }}$, maka Ho diterima \& Ha ditolak

c. Parasignifikasi

Uji parasignifikasi ini menggunakan £ sebesar 5\% dan df (derajat kebebasan $=$ jumlah data-2uji t dilakukan 2 sisi).

\section{HASIL ANALISIS DAN PEMBAHASAN}

\subsection{Dekripsi Objek Penelitian}

Dalam penelitian ini yang menjadi objek penelitiannya adalah perusahaan yang terdaftar di KPP Pratama Tanjung Karang. Dari hasil kuesioner tersebut, peneliti mendapatkan informasi yang menyangkut demografi responden sebagai berikut:

1. Jenis Kelamin

Dari hasil penyebaran kuesioner dengan 25 responden, diketahui bahwa 15 responden (0\%) adalah Laki-Laki dan sisanya sebanyak 10 orang (40\%) adalah Perempuan. 
2. Pendidikan

Berdasarkan informasi dari 25 responden, diketahui bahwa pendidikan terakhir yang ditempuh responden sampai saat ini sudah cukup tinggi, karena 20 responden $(80 \%)$ berada pada jenjang Strata 1, dan 5 responden (20\%) berada pada jenjang Strata 2. Hal ini membuktikan bahwa manajemen dalam organisasi perusahaan sudah memiliki pendidikan yang tinggi.

3. Lama bekerja pada organisasi yang bersangkutan

Dari hasil perhitungan kuesioner terhadap lamanya bekerja responden pada organisasi yang bersangkutan diperoleh bahwa sebanyak 8 responden $(32 \%)<1$ tahun, 14 responden (56\%) antara 1-3 tahun, dan sisanya 3 responden (12\%) antara 3-5 tahun. Dilihat dari segi lama bekerja pada organisasi yang bersangkutan, manajemen dalam organisasi perusahaan cukup memahami peraturan perpajakan dalam suatu perusahaan.

4. Usia

Berdasarkan informasi yang diperoleh dari 25 responden, diketahui bahwa sebanyak 8 responden $(32 \%)$ berusia $<25$ tahun, 12 responden $(48 \%)$ berusia 26-30 tahun, dan sisanya 5 responden (20\%) berusia 30-35 tahun.

\subsection{Analisis Kualitatif}

Analisis kualitatif yaitu menganalisis data dengan cara menguraikan data tersebut dalam bentuk kalimat secara terperinci dan sistematis. Untuk mengetahui presentase pencapaian score riil antara Pemahaman Manajemen Tentang UU No.36 tahun 2008 Terhadap Kepatuhan Wajib Pajak badan pada UU No.28 thn 2007.

\subsection{Analisis Kuantitatif}

Yaitu menganalisis pengaruh pemahaman manajemen tentang UU No.36 tahun 2008 (X) terhadap kepatuhan Wajib Pajak badan pada UU No.28 tahun 2007 (Y) dengan melakukan pengujian sebagai berikut :

\section{Analisis Korelasi Sederhana}

Untuk menganalisa adanya hubungan antara satu variabel dengan variabel yang lain, penulis menggunakan bantuan program Microsoft Office Excel 2007 untuk menganalisa data hasil penelitian.

2. Menghitung koefesien korelasi determinasi ( $r$ square atau $\mathbf{r}^{2}$ )

Untuk mengetahui besarnya kadar pengaruh antara Pemahaman Manajemen Tentang UU No.36 tahun 2008 (X) terhadap Kepatuhan Wajib Pajak badan pada UU No.28 tahun 2007, penulis menggunakan rumus Koefisien Penentu. Berdasarkan hasil perhitungan Koefisien Penentu di peroleh hasil nilai KP $=0,929$ atau 92,9\%.

\section{KESIMPULAN DAN SARAN}

\subsection{Kesimpulan}

1. Berdasarkan hasil analisis secara kualitatif, maka dapat disimpulkan sebagai berikut :

a. Pemahaman Manajemen Tentang UU No.36 tahun 2008 Terhadap Kepatuhan Wajib Pajak Badan Pada UU No.28 tahun 2007 secara umum sudah memahami dengan score pencapaian 911 dari score maksimum 1250 atau 72,88 \%, dalam artian bahwa manajemen organisasi dalam perusahaan telah memahami peraturan perpajakan yang telah ditetapkan UU No.36 tahun 2008. 
b. Kepatuhan Wajib Pajak badan pada UU No.28 tahun 2007 secara keseluruhan dapat dikatakan masuk kategori mematuhi dengan score pencapaian 908 dari score maksimum 1250 atau 72,64 \%, dalam artian manajemen organisasi dalam perusahaan selain memahami juga mematuhi kepatuhan Wajib Pajak badan pada UU No.28 tahun 2007.

2. Berdasarkan hasil analisis korelasi sederhana, maka dapat disimpulkan bahwa hubungan antara Pemahaman Manajemen Tentang UU No.36 tahun 2008 (X) terhadap Kepatuhan Wajib Pajak badan pada UU No.28 tahun 2007 (Y) mempunyai tingkat hubungan korelasi yang positif dan sangat tinggi, artinya jika manajemen paham tentang UU No.36 tahun 2008, maka akan meningkat kepatuhan Wajib Pajak badan di KPP Pratama Tanjung Karang, sedangkan untuk mengetahui besarnya kadar pengaruh antara Pemahaman Manajemen Tentang UU No.36 tahun 2008 (X) terhadap Kepatuhan Wajib Pajak badan pada UU No.28 tahun 2007, penulis menggunakan rumus Koefisien Penentu. Berdasarkan hasil perhitungan Koefisien Penentu di peroleh hasil nilai KP = 0,929 atau $92,9 \%$, dan sisanya sebesar $7,1 \%$ dipengaruhi oleh faktor lain.

3. Berdasarkan uji t dapat diuraikan korelasi antara pemahaman manajemen tentang $U U$ No.36 tahun 2008 (X) terhadap kepatuhan Wajib Pajak badan pada UU No.28 tahun 2007 (Y) ternyata $t_{\text {hitung }}>t_{\text {tabel }}$ atau 1,739>1,714 (hasil intervolasi pada $\alpha=0,05$ dan $n$ = 25) dengan demikian Ho ditolak dan Ha diterima, maka dapat dikatakan pemahaman manajemen tentang UU No.36 tahun 2008 berpengaruh positif dan signifikan terhadap kepatuhan Wajib Pajak badan pada UU No.28 tahun 2007.

\subsection{Saran}

- Manajemen perusahaan hendaknya memperdalam tiap butir pasal yang ada pada peraturan perpajakan yang berlaku saat ini tentang UU No.36 tahun 2008 seperti menghitung, memperhitungkan, membayar atau menyetorkan dan melaporkan kewajiban pajaknya.

- Perlu ditingkatkan keseriusan manajemen dalam memahami peraturan perpajakan Indonesia agar dapat menyelesaikan tugasnya dengan baik dan penuh tanggungjawab untuk memberikan data yang tepat dan akurat sehingga dapat meningkatkan kepatuhan Wajib Pajak badan di KPP Pratama Tanjung Karang.

\section{DAFTAR PUSTAKA}

Arsyad, Lincollin, M.Sc., Drs., Akuntansi Manajerial, Cetakan Pertama, Edisi 4, BPFEYogyakarta, Yogyakarta, 2008.

Handoko, T. Hani, M.B.A., Akt., Dr., Pengantar Manajemen, Cetakan 9, Edisi 2, BPFEYogyakarta, Yogyakarta, 1995.

Purnawan, Herman, dan Angriani, Eveline, Undang-Undang 2007 KU \& Tata Cara Perpajakan 2008, Penerbit Erlangga.

Regar, H., Moenaf, Pajak Penghasilan 1994, Cetakan Pertama, Penerbit Erlangga, 1995.

Mardiasmo, M.B.A., Ak., Dr., Perpajakan Edisi Revisi Tahun 2008, Penerbit Andi Yogyakarta. 
Susunan Dalam Suatu Naskah Undang-Undang Perpajakan Indonesia, Penerbit DBW Tax Center/PT. Warta Mitra Mandiri, 2010.

http:// ilhamhidayat.blog.com/ 2009/10/01/ tingkatan-manajemen-dan-manajer-danketerampilan-manajer/

http:// tlk4r.wordpress.com/ 2009/10/10/ pengaruh-penerapan-self-assessment-systemterhadap- tingkat- kepatuhan- wajib- pajak-badan-pada-kpp-dki-jakarta-khususnyajakarta-pusat/

http:// www.pajak.go.id/ index.php? view=article\&catid=98: hak-dan-kewajiban-wajibpajak\&id=916:kewajiban-wajib-pajak\&option=com_content\&Itemid=141

http:// www.pdf-finder.com/ MENINGKATKAN-KEPATUHAN-WAJIB-PAJAK-MELALUIKUALITAS-PELAYANAN.html 